\title{
JEL Classification M41
}

\author{
Цятковська Олена \\ к.е.н., доцент \\ кафедра обліку в кредитних і бюджетних установах \\ та економічного аналізу \\ ДВНЗ «Київський національний економічний університет ім. В. Гетьмана» \\ Київ, Україна \\ E-mail: elena.tsyatkovska@i.ua
}

\section{ОСОБЛИВОСТІ ОБЛІКУ ДОХОДІВ І ВИТРАТ СУБ'ЄКТАМИ ДЕРЖАВНОГО СЕКТОРУ ВІДПОВІДНО ДО НП(С)БОДС}

\begin{abstract}
Анотація
Bcmyn. Сучасна модель системи бухгалтерського обліку установ сектору загального державного управління формується за схемами ії модернізації, що визначено на законодавчому рівні. На даний час набув чинності новий план рахунків та національні стандарти положення бухгалтерського обліку в державному секторі, що суттєво змінило усталені методики обліку виконання кошторисів доходів і витрат бюджетних установ, інших господарських операцій відповідно до специфіки їх діяльності. Зазнала змін також економічна класифікація витрат, запроваджено поділ операцій на обмінні та необмінні відповідно до статистики державних фінансів та міжнародних стандартів бухгалтерського обліку для державного сектору. Зазначене призвело до значних змін у методииі обліку доходів та витрат, чим і обумовлена актуальність дослідження.

Методи. Інформаційною базою досліджень слуеувала створена автором база даних, зокрема, облікова документація щодо доходів і витрат та фінансова звітність 15 суб'єктів державного сектору. В якості джерела даних про стан нормативного регулювання обліку доходів і витрат суб'єктами державного сектору в Україні слугувала база даних «Законодавство України» Верховної ради України. Методика дослідження базується на теоретичних розробках та науковому інструментарії, що включав критичний аналіз фонансової звітності та кошториси підприємств державного сектору в Україні, а також аналіз нормативних документів українського законодавства, напрацювання вітчизняних науковців та практиків, а також нормативно-правові акти з питань організації, методики обліку доходів та витрат за обмінними та необмінними операціями.

Результати. У дослідженні розелянуто теоретичні, організаційні та методичні аспекти обліку доходів та витрат за обмінними та необмінними операціями суб'єктами державного сектору. Обгрунтовано на напрацьовано головні особливості методології обліку доходів та витрат за новими правилами бюджетними установами.

Перспективи подальших досліджень полягають в удосконаленні методики обліку доходів та витрат за обмінними та необмінними операціями бюджетними установами задля ефрективного управління державними фінансами.

Ключові слова: доходи, витрати, обмінні операції, необмінні операції, бюджетні установи, облік, суб'єкти державного сектору.

\section{Вступ.}

Методика обліку доходів і витрат суб'єктами державного сектору у зв'язку з набуттям чинності нових НП(С)БОДС з 01.01.2017 року зазнала значних змін, чим і обумовлюється актуальність теми дослідження. Відповідно до нових стандартів бухгалтерського обліку, перш ніж відобразити господарську операцію на субрахунках бухгалтерського обліку, необхідно визначити, до яких саме відноситься операція - до обмінних чи необмінних. Варто відмітити, що в НП(С)БОДС 124 «Доходи» та НП(С)БОДС 135 «Витрати» визначено, які операції з обліку доходів та витрат відносяться до обмінних чи необмінних, але особливості обліку і узагальнення інформації у бухгалтерській звітності потребує детального дослідження та систематизації відповідно до чинного Плану рахунків бухгалтерського обліку в державному секторі.
\end{abstract}




\section{Аналіз останніх досліджень та публікацій.}

Проблемні питання щодо обліку в державному секторі порушували та досліджували вітчизняні науковці С. В. Свірко, М. Р. Лучко, Л. Г. Ловінська, О.О.Дорошенко, Н.І.Сушко, О.О.Чечуліна, Т.В. Ларікова. Результати наукових доробків вищезгаданих вчених дають можливість стверджувати, що питання обліку доходів та витрат за обмінними та необмінними операціями потребує подальшого дослідження.

\section{Мета.}

За мету дослідження поставлено систематизацію та удосконалення методики обліку суб'єктами державного сектору через дослідження класифікації доходів та витрат які визначено в НП(С)БОДС.

\section{Методологія дослідження.}

Методологічною основою дослідження слугували напрацювання вітчизняних науковців та практиків, а також нормативно-правові акти з питань організації, методики обліку доходів та витрат за обмінними та необмінними операціями. Інформаційною базою досліджень слугувала створена автором база даних, зокрема, облікова документація щодо доходів і витрат та фінансова звітність 15 суб'єктів державного сектору. В якості джерела даних про стан нормативного регулювання обліку доходів і витрат суб'єктами державного сектору в Україні слугувала база даних «Законодавство України» Верховної ради України. Методика дослідження базується на теоретичних розробках та науковому інструментарії, що включав критичний аналіз фрінансової звітності та кошториси підприємств державного сектору в Україні, а також аналіз нормативних документів українського законодавства, напрацювання вітчизняних науковців та практиків, а також нормативно-правові акти з питань організації, методики обліку доходів та витрат за обмінними та необмінними операціями.

\section{Результати.}

Господарські операції бюджетних установ безпосередньо пов'язані із обліком витрат. Серед науковців до теперішнього часу існують окремі дискусії щодо розмежування та ідентифікації понять "витрати" та "видатки" в бюджетному обліку. Відповідно до Бюджетного кодексу України:

- видатки бюджету - це кошти, спрямовані на здійснення програм та заходів, передбачених відповідним бюджетом;

- витрати бюджету - це видатки бюджету, надання кредитів з бюджету, погашення боргу та розміщення бюджетних коштів на депозитах, придбання цінних паперів.

Реформи в бухгалтерському обліку бюджетних установ, що стосуються обліку витрат, розпочалися зі спроби сформувати нові підходи до їх визнання, оцінки та класифікації. Починаючи 3 2017 року набрали чинність нові НП(С)БОДС, що мали на меті наблизити український бухгалтерський облік до міжнародних стандартів. Тому при розгляді критичного питання про облік витрат необхідно керуватися НП(С)БОДС 135 «Витрати» [5]. Однак, зазначеного удосконалення методології бухгалтерського обліку витрат установ державного сектору було недостатньо, тому виникла потреба подальших змін, кінцевою метою яких $€$ визначення більш чітких критеріїв визнання операцій, а також витрат обмінними чи необмінними.

Інформація відносно доходів та витрат суб'єктів державного сектору узагальнюється та відображається у формі №2-дс «Звіт про фрінансові результати». Форма звіту та порядок складання регламентується НП(С)БОДС 101 «Подання фінансової звітності». У додатку 1 до НП(С)БОДС 101 «Подання фінансової звітності» - у формі № 2-дс «Звіт про фрінансові результати» - наведено класифікацію доходів від обмінних операцій та необмінних операцій.

Так, до доходів розпорядників бюджетних коштів від обмінних операцій належать: бюджетні асигнування; доходи від надання послуг; доходи від продажу; фінансові доходи; інші доходи від обмінних операцій[4]. 
Доцільно буде визначити, як така класифікація узгоджується з визначенням доходів від обмінних операцій, наведеним у п. 3 розд. I НП(С)БОДС 124 «Доходи», а саме: «обмінна операція це господарська операція з продажу/придбання активів в обмін на грошові кошти, послуги (роботи), інші активи або погашення зобов'язань».

Отже, відповідно до основних положень НП(С)БОДС 124 «Доходи» під обмінною операцією розглядається операція щодо придбання активів в обмін на грошові кошти, послуги (роботи), інші активи або погашення зобов'язань. Із запропонованих варіантів бюджетній установі підходять, поперше, розрахунки грошовими коштами, що виділяються установі у вигляді бюджетних асигнувань або отримуються нею за надання платних послуг. По-друге, придбання активів в обмін на погашення зобов'язань перед установою. Що стосується придбання активів в обмін за надані послуги (роботи), інші активи, то, згідно з п. 6 ст. 45 Бюджетного кодексу проведення розрахунків 3 бюджетом у негрошовій формі, у тому числі шляхом взаємозаліку, застосування векселів, бартерних операцій, зарахування зустрічних платіжних вимог у фінансових установах заборонено. 3 цієї ж причини в разі продажу активів установи можуть або прийняти грошові кошти, або скоротити свої зобов'язання. 3 урахуванням такого аналізу, наведене в НП(С)БОДС 124 визначення обмінної операції у частині придбання активів можна сформулювати наступним чином : обмінна операція розпорядника бюджетних коштів - це господарська операція із продажу/придбання бюджетною установою основних засобів, нематеріальних активів та запасів, визнаних такими відповідно до НП(С)БОДС 121, 122, 123, надання/оплати послуг та робіт, проведення платежів, у тому числі податкових (за виключенням ПДВ), пов'язаних із виконанням установою належних ій функцій, в обмін на грошові кошти у вигляді бюджетних асигнувань та надходжень від надання платних послуг або в обмін на погашення зобов'язань.

Однак, установи в процесі виконання своїх функціональних обов'язків не лише купляють нефінансові активи, а й оплачують необхідні послуги, наприклад з постачання енергоносіїв, мають проводити оплату відряджень, витрачатися на проведення інших цільових заходів (олімпіад, спортивних змагань тощо), розраховуватися з бюджетом у вигляді рентних платежів, податків, наприклад за землю, проводити інші платежі, наприклад оплату судового збору в разі направлення позову до суду задля повернення бюджетних активів тощо. По суті, пов'язані з цим операції також $є$ обмінними, адже в обмін на отримані кошти за загальним або спеціальним фондом установа виконує належні їй функції.

Варто відзначити, що нормами НП(С)БОДС 124, де в пп. 2.3 п. 2 розд. II «Доходи від обмінних операцій» визначено про витрачання бюджетних асигнувань, що є доходами від обмінних операцій, на виконання установою своїх повноважень. Аналогічно установа здійснюе діяльність, визначену для неї законодавством і положенням (статутом) і за рахунок надходжень від надання нею платних послуг та робіт.

Відповідно до Плану рахунків бухгалтерського обліку в державному секторі від 31.12.2013 № 1203 облік доходів розпорядників бюджетних коштів ведеться на рахунках 7-го класу «Доходи», який включає рахунки і субрахунки подані в табл. 1.

Ураховуючи викладене, не зовсім зрозумілим є включення до п. 3 розд. II НП(С)БОДС 124, присвяченого доходам від необмінних операцій, норми стосовно поводження 3 авансовими платежами. Адже в ході проведення господарських операцій, які вище кваліфікували як обмінні, можуть бути проведені авансові платежі як установою, так і на користь установи.

Звертаємо також увагу, що в цьому ж розділі йдеться про такий вид доходів, як безоплатно отримані установою товари, роботи, послуги (п. 3.6) та грошова благодійна допомога (п. 3.7). Тим самим вони визнані доходами від необмінних операцій.

По суті, до безоплатно отриманих можна віднести й лишки активів, що виявляються під час інвентаризації, зокрема ті, що використовуються або плануються до використання установою для виконання нею своїх функцій. 


\section{Рахунки бухгалтерського обліку доходів}

Таблиия 1

\begin{tabular}{|c|c|c|}
\hline 70 & Доходи за бюджетн & мии асигнуваннями \\
\hline & 7011 & Бюджетні асигнування \\
\hline 71 & Доходи від реалізаь & iї продукції (робіт, послуг) \\
\hline & 7111 & Доходи від реалізації продукції (робіт, послуг) \\
\hline & 7112 & Дохід від оприбуткування активів, раніше не врахованих в балансі \\
\hline 72 & Доходи від продаж) & активів \\
\hline & 7211 & Дохід від реалізації активів \\
\hline 73 & Фінансові доходи & \\
\hline & 7311 & Фінансові доходи розпорядників бюджетних коштів \\
\hline 74 & Інші доходи за обмі & ними операціями \\
\hline & 7411 & Інші доходи за обмінними операціями \\
\hline 75 & Доходи за необмінн & ими операціями \\
\hline & 7511 & Доходи за необмінними операціями \\
\hline & 7512 & Трансферти \\
\hline
\end{tabular}

Потрібно відзначити, що їх доцільно визнавати все ж таки доходами від обмінних операцій, ураховуючи той фракт, що надходження від благодійників або виявлені лишки (назвемо їх безоплатними надходженнями) установа направляє, як і бюджетні асигнування та плату за послуги, на виконання своїх функцій. Тобто установа виконує повноваження в обмін на отримання таких ресурсів. Для більшої аргументації звернемося до НП(С)БОДС 135 «Витрати». Тут у п. 2 розд. II до витрат за обмінними операціями (як і у Звіті про фінансові результати) віднесено: витрати на оплату праці; відрахування на соціальні заходи; матеріальні витрати; витрати на амортизацію; інші витрати.

За всіма цими напрямами і витрачаються бюджетною установою безоплатні надходження в будь-якому вигляді.

I, якщо, зіставити в цій частині норми НП(С)БОДС 124 та НП(С)БОДС 135, то виходить, що за рахунок доходів від необмінних операцій ми проводимо видатки за обмінними операціями. Виглядає дещо нелогічно. Крім того, відобразити проведені за рахунок благодійних надходжень витрати як видатки за необмінними операціями неможливо через відсутність у Плані рахунків субрахунків для витрат за необмінними операціями для розпорядників бюджетних коштів.

Облік доходів ведеться накопичувальним підсумком з початку бюджетного року і до його завершення на пасивних рахунках Класу 7 «Доходи». Залишку ці субрахунки не мають, оскільки в кінці звітного періоду відображається закриття рахунків доходів на рахунок 5511 «Фінансовий результат виконання кошторису звітного періоду». Основні бухгалтерські проведення з обліку доходів подано в табл. 2.

Отже, в результаті проведеного аналізу наукових доробків та нормативно-правової бази, можна зробити висновок, що для обліку видатків за рахунок благодійних надходжень доцільним буде використовувати субрахунки 8111-8115, призначені для відображення витрат за обмінними операціями. А доходи відображати за необмінними операціями на 7511 «Доходи за необмінними операціями». Безумовно, про такий вибір субрахунків витрат з наведенням причин слід зазначити в наказі про облікову політику.

Якщо на законодавчому рівні встановлять вимогу визнавати безоплатні надходження, спрямовані на виконання функцій установи, доходами від обмінних операцій, то наведене і сфрормульоване визначення обмінної операції буде розширене таким джерелом придбання активів, робіт і послуг, як благодійні надходження.

За показниками форми № 2-дс до доходів розпорядників бюджетних коштів від необмінних операцій належать: податкові надходження; неподаткові надходження (збори та платежі); трансфрерти; інші доходи від необмінних операцій [8]. 


\section{Основні бухгалтерські проведення з обліку доходів за обмінними та необмінними}

Таблиця 2 операціями

\begin{tabular}{|l|l|l|}
\hline \multicolumn{1}{|c|}{ 3міст господарської операції } & \multicolumn{1}{|c|}{ Дебет } & \multicolumn{1}{|c|}{ Кредит } \\
\hline \multicolumn{1}{|c|}{ Облік доходів за обмінними операціями } & 7011 \\
\hline $\begin{array}{l}\text { Отримання асигнувань установами, які утримуються за рахунок коштів державного } \\
\text { бюджету }\end{array}$ & 2313,2311 & 7111 \\
\hline Нарахування суми надходжень від реалізації робіт, послуг, виробів і продукції & 2111,6212 & 7112 \\
\hline $\begin{array}{l}\text { Оприбуткування раніше не врахованих на балансі основних засобів, які виявлені в } \\
\text { результаті інвентаризації та будуть використовуватися для потреб установи } \\
\text { Водночас проведення другого запису }\end{array}$ & 10 & 5111 \\
\hline Нарахування доходів від реалізації активів & 7112 & 7211 \\
\hline $\begin{array}{l}\text { Відображення дивідендів та відсотків, що підлягають отриманню відповідно до } \\
\text { законодавства суб'єктом державного сектору }\end{array}$ & 2117 \\
\hline $\begin{array}{l}\text { Нараховано плату за оренду майна } \\
\text { Відновлення корисності об'єктів основних засобів після усунення причин попереднього } \\
\text { зменшення їх корисності }\end{array}$ & 14117 \\
\hline Облік доходів за необмінними операціями & 2117 \\
\hline $\begin{array}{l}\text { Відображено дохід від безоплатно отриманих нематеріальних активів (крім } \\
\text { внутрішнього переміщення в межах органу, уповноваженого управляти об'єктами } \\
\text { державної (комунальноі) власності) }\end{array}$ & 7411 \\
\hline Отримання спонсорських, благодійних внесків та іншої гуманітарної допомоги & 2311 \\
\hline
\end{tabular}

Такий перелік деталізований (скоріш за все, у частині інших доходів від необмінних операцій) у пп. 1.2 та п. 3 розд. II НП(С)БОДС 124. Доходами від необмінних операцій визнані: кошти, що отримують бюджетні установи для виконання цільових заходів від інших установ та організацій; зобов'язання, що не підлягають погашенню; безоплатно отримані товари, роботи, послуги; сума безоплатної допомоги.

Знову ж таки, прослідкуємо зв'язок наведених видів доходів з визначенням необмінної операції, наведеним у п. 3 розд. 1 НП(С)БОДС 124, а саме: «необмінна операція - це господарська операція, яка не передбачає передачі активів, послуг (робіт) в обмін на отриманий дохід або активи, але може передбачати виконання певних умов».

Можливо, таке визначення підходить для операцій із податками або із зобов'язаннями, що не підлягають погашенню (напевне, тут ідеться про списання на доходи безнадійної кредиторської заборгованості).

Погодитися можна і з віднесенням до доходів за необмінними операціями коштів, що отримують бюджетні установи для виконання цільових заходів від інших установ та організацій, що передбачає виконання установою неналежних функцій. Наприклад, якщо органи соціального захисту перераховують установі кошти для оплати додаткової відпустки працівникам, що є особами, постраждалими від Чорнобильської катастрофи, або навчальним закладам для виплати студентам соціальної стипендії. Витрати під час таких операцій згідно з п. 2 розд. ॥ НП(С)БОДС $135 є$ витратами за необмінними операціями.

Що стосується трансфертів, то назвати їх отримання та перерахування доходами та витратами за необмінними операціями можна із впевненістю лише щодо трансфертів на міжбюджетному рівні, наприклад, субвенції із держбюджету місцевим бюджетам. Якщо ж ітиметься про трансфрерти, що управліннями соціального захисту надаються, наприклад, населенню, то вони виконують ці операції в рамках покладених на них функцій, які повністю разом із цими 
трансфертами фінансуються за рахунок бюджетних асигнувань. Варто відмітити, що згідно з пп. 2.3 розд. II НП(С)БОДС 124 та пп. 3.1 розд. ІІІ НП(С)БОДС 135 усі операції за рахунок бюджетних асигнувань для виконання установою своїх повноважень є обмінними. Це саме стосується і сплати штрафів та пені.

У разі якщо виконання установою своїх функцій визнати головною ознакою для визначення характеру доходів та операцій, то тоді й безоплатні надходження, отримані в обмін на виконання установою своїх функцій, мають бути віднесені до доходів від обмінних операцій.

Якщо, знову ж таки, орієнтуватися на таку ознаку, то до доходів за необмінними операціями, тобто непов'язаними з виконанням установою своїх функцій, можна віднести доходи від непотрібних установі виявлених надлишків цінностей, запчастин та металобрухту від розбирання списаних основних засобів, непотрібну необоротну тару, що накопичилася в процесі діяльності і яку можна реалізувати, адже продаж товарів - це, дійсно, операція, не пов'язана з виконанням установами своїх функцій.

Якщо ж орієнтуватися лише на вищенаведене визначення необмінної операції, за яким передавач активів не отримує доходу, то визнаються доходами від необмінних операцій й бюджетні асигнування, адже взамін на активи у вигляді таких асигнувань бюджет доходів не отримує, а лише наполягає на виконанні певних умов, а саме забезпеченні установами виконання своїх функціональних обов'язків. Але ж наведені вище норми кажуть про протилежне.

Основні бухгалтерські проведення з обліку витрат розпорядників бюджетних коштів подано в табл. 3.

Таблиця 3

Основні бухгалтерські проведення з обліку витрат за обмінними та необмінними операціями

\begin{tabular}{|c|c|c|}
\hline 3міст господарської операції & Дебет & Кредит \\
\hline \multicolumn{3}{|l|}{ Облік витрат за обмінними операціями } \\
\hline Нарахована амортизація основних засобів & 8014 & 1411 \\
\hline Відображення втрат від зменшення корисності об'єктів основних засобів & 8411 & 1411 \\
\hline Вибуття запасів у випадках, передбачених законодавством & 8013,8113 & 15,18 \\
\hline Списання грошових документів на підставі акта & 8013,8113 & 2116 \\
\hline Прийняття та затвердження звіту про використаний аванс & 8411 & 2116 \\
\hline Нараховано ЄСВ & 8012,8112 & 6313 \\
\hline Нараховано ЗП & 8011,8111 & 6511 \\
\hline \multicolumn{3}{|l|}{ Облік витрат за необмінними операціями } \\
\hline Списання сум дебіторської заборгованості після закінчення строку позовної давності & 8511 & $\begin{array}{l}2113, \\
2117\end{array}$ \\
\hline Нараховано соціальні стипендії & 8511 & 6512 \\
\hline $\begin{array}{l}\text { Нараховано суми субсидій, допомоги, пільг з оплати спожитих житлово-комунальних } \\
\text { послуг та послуг зв'язку }\end{array}$ & 8511 & 6414,6415 \\
\hline
\end{tabular}

Доцільно відзначити, що витратами за необмінними операціями за визначенням як форми № 2-дс, так і НП(С)БОДС 135, є транссрерти, операції з коштами, отриманими на виконання цільових заходів, та списана дебіторська заборгованість.

\section{Висновки і перспективи.}

За результатами досліджень стає очевидним, що основними завданнями бухгалтерського обліку доходів і витрат розпорядників бюджетних коштів $€$ забезпечення контролю за витрачанням бюджетних коштів відповідно до затверджених кошторисом та відповідно до їх цільового призначення. Крім того, облікові дані сприяють забезпеченню всіх рівнів управління інформацією про рух і використання бюджетних коштів.

Згідно з діючими нормами НП(С)БОДС 124 та НП(С)БОДС 135 бюджетні асигнування, доходи від надання послуг, а також витрати на виконання установою свої повноважень, що покриваються за рахунок бюджетних асигнувань і витрати, пов'язані з наданням послуг, $є$, 
відповідно, доходами та витратами за обмінними операціями. Існують певні неузгодженості між складом доходів та витрат за необмінними операціями. Для суттєвого зменшення кількості спірних питань законодавцем заплановано внесення змін до вказаних стандартів.

\title{
Список використаних джерел
}

1. Бухгалтерский облік і контроль державного сектору в умовах модернізації управління державними фінансами: у 2 т. ; за ред. Л.Г. Ловинської. Т. 1: Реформування бухгалтерського обліку в державному секторі відповідно до міжнародних стандартів / Л.Г. Ловінська, Н.І. Сушко, С.В.Свірко та ін. Київ : ДННУ «Акад.фін.управління», 2013. 568 с.

2. Інструкції щодо застосування економічної класифікації видатків бюджету [Електронний ресурс]: наказ Міністерства фінансів України від 12.03.12 р. № 333. URL: http://zakon3.rada.gov.ua/laws/show/z0456-12 (дата звернення 12.10.2017).

3. Ловінська Л. Г. Класифікація рахунків бухгалтерського обліку в державному секторі за економічним змістом у контексті запровадження нового плану рахунків. Фінанси України. 2016. № 1. С. 99-115.

4. Національне положення (стандарт) бухгалтерського обліку в державному секторі 124 «Доходи» : Наказ Міністерства фрінансів України від 24.12.2010 № 1629 URL : http://zakon5.rada.gov.ua/laws/show/z0089-11 (дата звернення 12.10.2017).

5. Національне положення (стандарт) бухгалтерського обліку в державному секторі 135 «Витрати» : Наказ Міністерства фінансів України від 18.05.2012 № 568 URL : http://zakon3.rada.gov.ua/laws/show/z0903-12 (дата звернення 13.10.2017).

6. Про затвердження деяких нормативно-правових актів з бухгалтерського обліку в державному секторі: наказ Міністерства фінансів України від 29.12.2015 р. № 1219. URL: http://zakon2.rada.gov.ua/laws/show/z0085-16/page (дата звернення 11.10.2017).

7. Про затвердження Плану рахунків бухгалтерського обліку в державному секторі: Наказ $\begin{array}{llllll}\text { міністерства фонансів України від } 31.12 .13 & \text { № } 1203 & \text { URL: }\end{array}$ http://195.78.68.18/minfin/control/uk/publish/article?showHidden=1\&art_id=389725\&cat_id=363499\&ctime=138 7183247121 (дата звернення 19.10.2017).

8. Про затвердження порядку заповнення форм фінансової звітності в державному секторі та Змін до Національного положення (стандарту) бухгалтерського обліку в державному секторі 101 "Подання фінансової звітності" [Електронний ресурс]: наказ Міністерства фінансів України від 28.02.17 р. № 307 . URL : http://zakon5.rada.gov.ua/laws/show/z0384-17 (дата звернення 19.10.2017).

9. Свірко С.В. Організація бухгалтерського обліку в бюджетних установах. Київ : КНЕУ, 2004. 380 с.

10. Юнгман, Й. Бюджетный процесс как инструмент эфффективного управления. Правительственная канцелярия. Стокгольм, 2005. 255 с.

11. Public sector accounting reforms in Ukraine. TCOP Workshop: Experiences with Designing and Implementing Public Sector Accounting Reforms. 2011. Available at: http://www.pempal.org/event/eventitem/read/41/88 (дата звернення 16.10.2017).

Статтю отримано: 11.10.2017 / Рецензування 10.11.2017 / Прийнято до друку: 14.12.2017

\author{
Olena Tsiatkovska \\ Ph.D. (in Economics), Associate Professor \\ Department of Accounting Credit and Budget institutions \\ and economic analysis \\ Kyiv National Economic University named after Vadym Hetman \\ Kyiv, Ukraine \\ E-mail: elena.tsyatkovska@i.ua
}

\section{THE CHARACTERISTICS OF INCOME AND EXPENCES ACCOUNTINGBY PUBLIC SECTOR ENTITIES}




\section{Abstract}

Introduction. The up-to-date model of the accounting system in the institutions of general government management sector is formed according to the schemes of its modernisation and it is defined at the legislative level. The new chart of accounts and national standards of accounting regulations in public sector that changed the established accounting techniques for the execution of budget income and expenditure in budget institutions, and other business transactions according to the peculiarities of their activity have been realized. The economic classification of expenditures has been changed, the operations are divided into exchange and non-exchange according to public finance statistics and international accounting standards for the public sector. Significant changes in accounting method of income and expenses made this issue up to the improvement of income and expenses accounting methods for public sector entities.

Methods. The author created the data basis of original financial documentation of 15 distribution enterprises in Ukraine over the period of 2012-2017 to provide the informative basis of empirical research studies.

The data source on the condition of normative regulation of income and expenditure accounting by public sector entity, analitical activities of controllers in Ukraine was the data basis of legislative acts of Verkhovna Rada of Ukraine. Research methodology is based on theoretical insights into the problem and scientific instrumentation that contained the critical content-analysis of original financial statements of public sector enterprises in Ukraine, comparative analysis of normative documents of Ukrainian legislative acts and experience of Ukrainian scientists and experts in the field of organization, procedure of income and expenditure accounting according to exchange and non-exchange operations.

Results. The article examined the theoretical, organizational and methodological aspects of income and expenses accounting for the exchange and non-exchange operations of the public sector entities. The basic features of accounting methodology of income and expenses according to new rules of financial institutions are determined. Further research can be focused on improving the methodology of income and expenses accounting for the exchange and non-exchange operations by financial institutions for effective management of public finances.

Keywords: income, expenditures, exchange transactions, non-exchange transactions, budgetary institutions, accounting, entity.

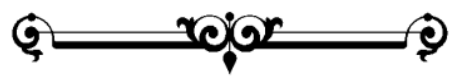

